\title{
Introduction to manipulation
}

\author{
K. A. I. Keir MCSP, Dip TP and G. C. Goats PhD, MCSP \\ School of Physiotherapy, the Queen's College, Glasgow, UK
}

\section{Origins}

The art of manipulation was known to Hippocrates and the physicians of ancient Rome, and has passed down a long line of medical manipulators and bonesetters to present day practitioners; osteopaths, physiotherapists, chiropractors and manipulating physicians and surgeons. Osteopathy and chiropractic, unlike physiotherapy, at present remain outside orthodox medical practice in the UK.

The subject has always been contentious, often acrimonious, with much factional and interprofessional rivalry, but in the late 20th century the practice of manipulation is finally achieving scientific respectability through the application of biomechanical principles and recent advances in neurophysiology, together with a serious attempt to prove efficacy through controlled randomized clinical trials. Thus osteopathy and chiropractic may yet be extended a guarded welcome into the orthodox medical fold.

This paper will describe briefly the terminology used in manipulation and discuss patient assessment, indications for treatment and the common manipulative techniques. A review of present knowledge of the physiological effects of manipulation will accompany a discussion of clinical outcomes based upon data from clinical research.

Osteopatiny and chiropractic were both founded in the USA during the late 19th century. Andrew Still, the father of osteopathy, based his treatment on the belief that all symptoms arose from abnormalities of segmental motion, whilst David Palmer, the founder of chiropractic, was convinced that symptoms of disease in other body systems developed from changes in vertebral alignment ${ }^{1}$.

Within orthodox medicine, physiotherapy is acknowledged to play an important role in the management of musculoskeletal problems. Central to practice is the use of manual skills, including massage and passive joint manipulation. Physiotherapists may work either independently or in conjunction with their medical manipulator colleagues, whose work extends to manipulation under anaesthesia. This procedure will not be covered here.

Address for correspondence: Mrs K. Keir, School of

Physiotherapy, Faculty of Health Studies, The Queen's College,

Crawfurd Building, Southbrae Campus, Southbrae Drive,

Jordanhill, Glasgow G13 1PP, UK

(C) 1991 Butterworth-Heinemann Ltd

0306-3674/91/040221-06
Techniques have developed along similar lines in each of the professions, regardless of the philosophy governing their use, with only minor differences of interpretation.

\section{Terminology}

Any discussion amongst manipulators is hampered by a vocabulary that means different things to different people, the gulf never greater than between the general public and the medically qualified. Perhaps the most accurate description of manipulation is given by the Oxford Dictionary: 'to work with the hands, to handle or manage'. Many lay people erroneously believe that the term implies the use of fast jerking techniques, and carries with it the stigma of 'quackery' or connotations of 'putting bones back' by the use of large amounts of ill-advised force and small amounts of brain power.

Those who employ manual techniques as the tools of their trade use the term manipulation to encompass a wide variety of procedures from the most gentle to very vigorous, including both low- and high-velocity applications (Figure 1). The wealth of techniques available is described fully and illustrated elsewhere $^{2-7}$.

Manipulative therapy procedures are applied passively to the patient who does not actively participate apart from giving consent. These may be usefully subdivided into (1) soft tissue techniques, (2) mobilization techniques applied to joints, and (3) manipulation or high-velocity thrust techniques also applied to joints.

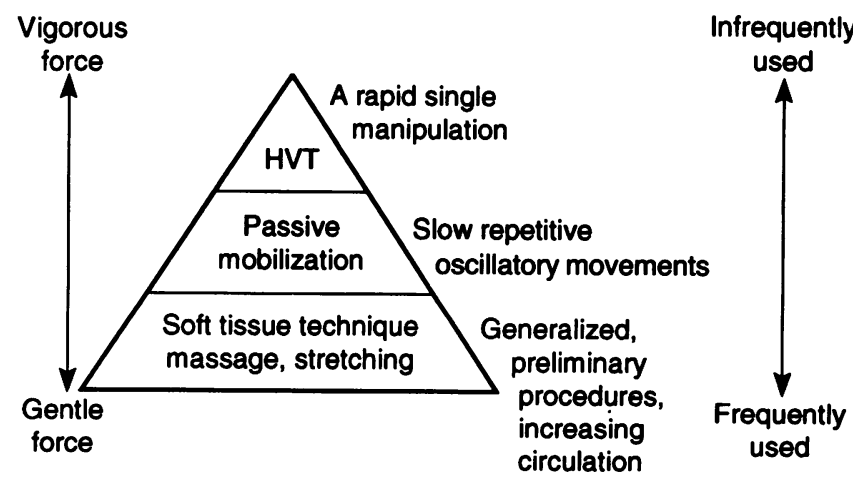

Figure 1. The types of manipulative therapy ranked according to force applied and frequency of use. HVT, high-velocity thrust 


\section{Soft tissue techniques}

Traditional massage falls into this category and is applied to muscles, fascia and ligaments. These techniques are dealt with thoroughly elsewhere ${ }^{8-10}$, and this paper will only discuss the manipulation of joints.

\section{Mobilizations}

These techniques are amongst the most common used in the treatment of musculoskeletal problems and are either repetitive oscillatory movements, or sustained stretches at the end of range. Such procedures remain under the patient's control. Mobilizations can be divided into localized 'specific' procedures, and more generalized techniques.

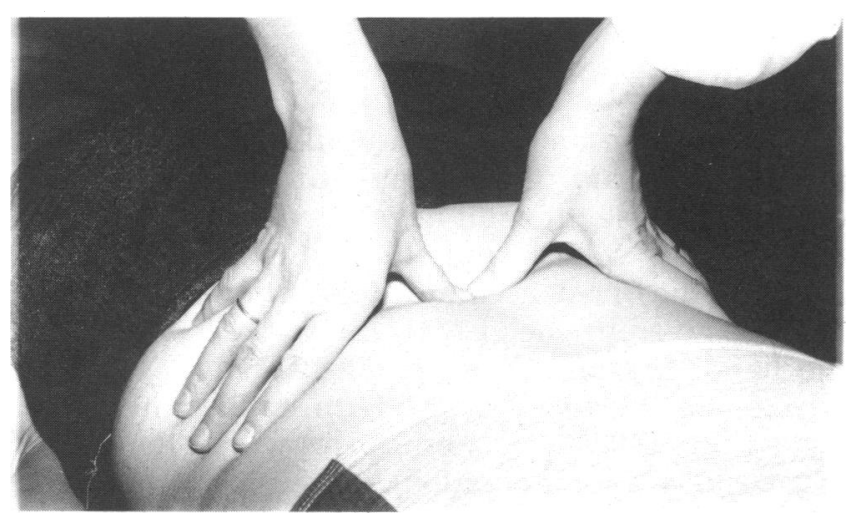

Figure 2. Pressure applied through a spinous process in the lumbar spine in a posteroanterior direction

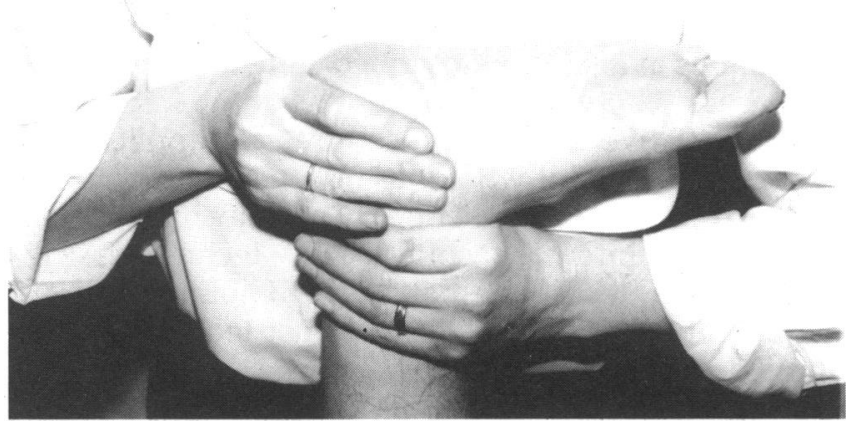

Figure 3. Translatory movement of the talocalcaneal joint

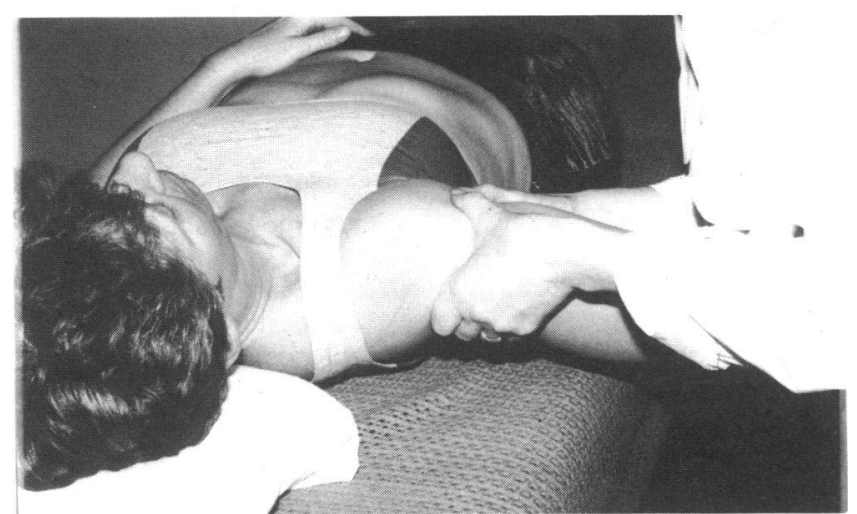

Figure 4. Translatory movement of the glenohumeral joint
As the name suggests, specific techniques act directly on the joint involved, with the operator using anatomical structures as levers. Spinous and transverse processes of the vertebral column are frequently employed as short levers (Figure 2) to produce translatory gliding and rotation of neighbouring articular surfaces in the accessory range of movement ${ }^{11,12}$.

In a peripheral joint, the proximal bone of the articulation needs to be carefully fixed so that its distal partner may be moved, e.g. in the talocalcaneal joint the talus is fixed so that the effects of a translatory glide of the calcaneum are localized (Figure 3), and the scapula is fixed by the patient's weight to allow translatory gliding of the humeral head in the glenoid fossa (Figure 4).

Non-specific generalized techniques, such as rotation of the lumbar spine, use longer levers offered by the shoulder, pelvic girdle or limbs, and produce their effects over several joints. The force required in these situations is proportionately reduced by the greater leverage ${ }^{13}$.

\section{Manipulation or thrust techniques}

A manipulation consists of a single high-velocity thrust applied to a joint, or series of joints and associated soft tissues. The aim is usually to restore lost movement and to relieve pain. These techniques are only performed on a relaxed patient. A manipulative thrust technique momentarily takes the joint further than its normal physiological range. Accurate localization of the joint position before the technique, followed by a skillfully applied thrust, will result in a movement which is so fast that it is complete almost before the patient knows it has begun ${ }^{14}$.

This procedure is sometimes indicated when a joint fails to achieve full mobility after mobilization. Although used mainly in the treatment of spinal problems, manipulation can be employed to treat the shoulder or sacroiliac joints, and the small joints of the hand and foot ${ }^{14}$.

\section{Examination and assessment}

Every manipulator, regardless of his professional origin, must identify accurately the site of the lesion before treatment. Manipulative therapy aims to be effective and efficient, but above all safe. The good practitioner will meticulously examine the patient to exclude contraindications (Table 1) and identify the structure causing the problem, be it a joint, ligament or muscle ${ }^{3,6,15}$.

The contribution of James Cyriax to the analysis of musculoskeletal problems is invaluable. Most manipulators examine patients using methods developed by him, although upon this foundation many refinements have been added ${ }^{1,6,15}$. The distribution of symptoms and behaviour of pain at rest and during activity through a 24 -h period are noted, together with a detailed account of the onset.

This information is interpreted by the therapist and further tests conducted until the faulty structure is located. In particular, discrepancies between active 
Table 1. Contraindications to manipulative therapy

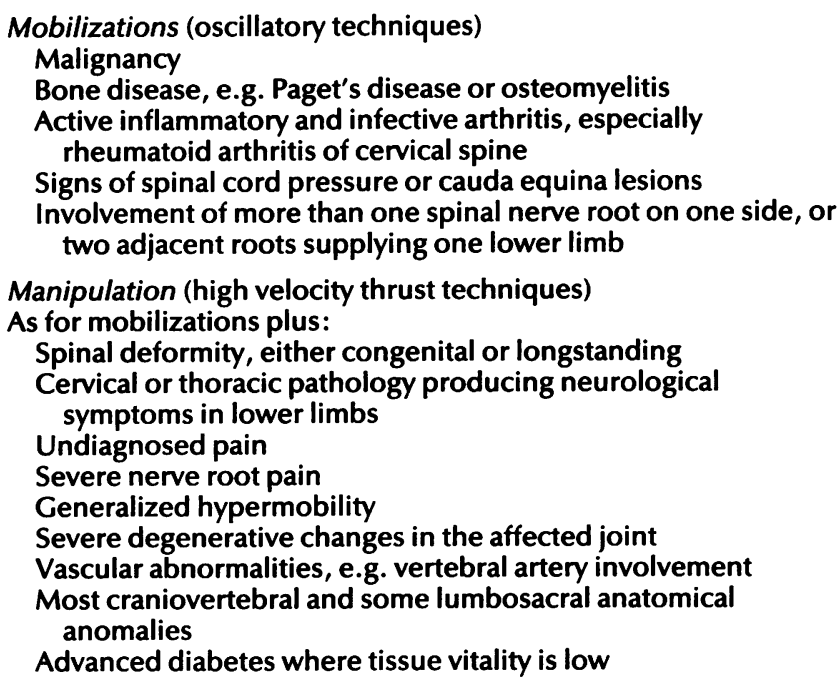

and passive movement are identified, measured and analysed. The importance of this process cannot be understated as it forms the baseline for implementing and evaluating all subsequent manipulative procedures.

\section{Indications}

Manipulative therapy is indicated by pain and dysfunction of musculoskeletal origin, either of longstanding or of recent onset, occurring in vertebral and peripheral joints. Manipulation is not the panacea for every complaint of mechanical origin, but skilfully employed at the correct stage, it can yield considerable benefit ${ }^{3,6,15}$.

Most joint problems can be placed into two categories, those which will respond quickly to treatment, e.g. an acute wry neck, and those whose pathology or injury generally respond slowly, e.g. whiplash injury. The so-called 'miracle cures' frequently extolled by sufferers are often problems readily amenable to manipulative procedures. Often the manipulator will recognize that prompt assessment and an accurately localized intervention will hasten the healing that would eventually occur naturally. Occasionally unscrupulous operators will exploit this to preserve the mystique of manipulation.

\section{Contraindications}

The manipulator who has full knowledge of the patient's medical status knows clearly those situations in which thrust techniques are absolutely contraindicated and those where mobilizations are unwise ${ }^{14}$.

Diseases and injuries of the bone and joints completely contraindicate thrust techniques. Gentle mobilization and soft tissue procedures can be used safely in situations where thrust techniques could not, such as severe nerve root entrapment syndromes (Table 1).

\section{Physiological effects}

The effects of manipulation upon physiological mechanisms remain inadequately investigated experimentally. Some data exist and the important contributions are reviewed briefly below.

\section{Relief of pain}

The pain-gate theory and recent advances in articular neurology offer a possible physiological explanation for the analgesic effects of manipulation in the treatment of pain and muscle spasm $^{16,17}$. Large diameter afferent fibres embedded in the joint capsule and associated ligaments ${ }^{16}$ are stimulated by the tension produced by manipulation. This activity inhibits the small diameter nociceptor afferent input to the ascending pathways in the spinal cord, thus reducing the experience of pain at a cortical level ${ }^{18}$. Reflex protective muscle spasm, frequently a result of pain, will clearly reduce as pain subsides ${ }^{14}$, thus reducing discomfort further.

However, Zusman ${ }^{19}$ challenges Wyke, reporting electrophysiological studies on cats and primates that show insufficient numbers of large diameter joint afferents are stimulated by oscillatory passive movements to reduce joint pain by pain-gating. Hence passive movements performed on an inflamed joint are likely to stimulate rather than inhibit nociceptor activity. These findings lead to the conclusion that the analgesic effect of passive joint movement is mediated by the endogenous opiate neurotransmitters active in the descending pain suppression mechanism ${ }^{20,21}$.

A further alternative view is offered ${ }^{21}$ that an effective, albeit temporary, decrease in the perception of pain occurs by inhibition of reflex muscle contraction through the stimulation of joint afferents by an end of range passive movement.

\section{Increased joint range}

Where resistance to movement is due to tissue tension rather than pain, such as the contracture of a capsule or ligament after immobilization, treatment is aimed at elongating these structures to restore joint mobility.

The force required to stretch a ligament from zero tension to failure, and the deformation which results, can be depicted on a stress-strain curve (Figure 5). This shows that the ligament exhibits first elastic and then plastic behaviour before failure, and that this represents different stages of collagen deformation. The 'toe' phase and 'linear' phase lie within the elastic region, and elongation of a normal ligament under these conditions is completely reversible.

In the toe phase, single collagen fibres at rest are usually corrugated. The sinuous shape adopted is referred to as 'crimp'. When stress is applied to a collagen fibre, the initial effect is to straighten the crimp and 'take up the slack' (Figure 5). During the 'linear phase', under a continued slow sustained stretch, the normally oblique lattice work of collagen fibres realign themselves in the direction of the force applied. Proteoglycans (large protein molecules) and 
water are displaced and bonds within individual collagen fibres become strained.

If further stretch is applied, the structure displays a characteristic 'plasticity' (Figure 5) at the point where

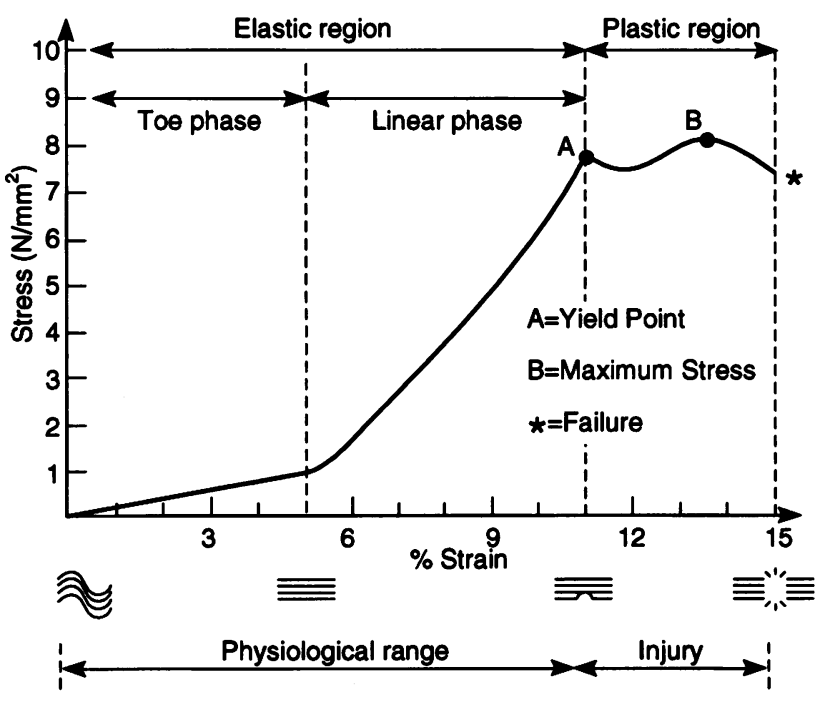

至 $=$ Stages of deformation range of collagen

Figure 5. Normal stress-strain curve for a ligament some irreversible lengthening begins, and failure of the material becomes likely ${ }^{11,21}$. Thus, in a shortened structure, the application of a slow sustained force, such as a mobilization technique used at the end of range, should be applied to stress the ligament and capsule into the beginning of 'plastic' range. This will cause a degree of permanent tissue lengthening without inducing failure of the structure ${ }^{22}$.

Manipulative techniques not only help regain movement, but also normalize the stresses upon muscles, collagenous tissues, blood and lymphatic vessels, thus improving their function ${ }^{14,15}$. Controlled passive movement of joints has also been shown to increase the rate of tendon repair and decrease friction between a tendon and its sheath during the repair process ${ }^{23}$.

\section{Psychological effects}

Undoubtedly the psychological effect of skilful handling and the feeling that the manipulator has located the spot exerts a powerful placebo influence that contributes to the potency of manipulative procedures. This remains unquantified ${ }^{\mathbf{1 4}}$.

Table 2. Comparative trials of spinal manipulation

\begin{tabular}{|c|c|c|c|c|c|c|}
\hline Authors & Year & $\begin{array}{l}\text { Number } \\
\text { in trial }\end{array}$ & $\begin{array}{l}\text { Duration of } \\
\text { symptoms }\end{array}$ & $\begin{array}{l}\text { Control } \\
\text { treatment }\end{array}$ & Study treatment & Results \\
\hline Coxhead et al. ${ }^{35}$ & 1981 & 334 & $\begin{array}{l}\text { Average } 14 \\
\text { weeks }\end{array}$ & $\begin{array}{l}\text { SWD and } \\
\text { back care talk }\end{array}$ & $\begin{array}{l}\text { 1. Manipulation/ } \\
\text { mobilization } \\
\text { 2. Exercises } \\
\text { 3. Traction } \\
\text { 4. Corset }\end{array}$ & $\begin{array}{l}\text { Manipulation group had significantly less } \\
\text { pain. More treatment led to more } \\
\text { improvement }\end{array}$ \\
\hline Evans et al. ${ }^{28}$ & 1978 & 32 & $>3$ weeks & $\begin{array}{l}\text { Cross-over } \\
\text { design }\end{array}$ & $\begin{array}{l}\text { Analgesics and } \\
\text { manipulation }\end{array}$ & $\begin{array}{l}\text { Significant results in group who had } \\
\text { manipulation first. Pain less, mobility } \\
\text { increased }\end{array}$ \\
\hline Fisk $^{29}$ & 1979 & 20 & $<35$ days & $\begin{array}{l}10 \text { normal } \\
\text { subjects }\end{array}$ & $\begin{array}{l}\text { Non-specific } \\
\text { manipulation }\end{array}$ & $\begin{array}{l}\text { Significant improvement in SLR in back pain } \\
\text { subjects after manipulation }\end{array}$ \\
\hline Glover et al. ${ }^{30}$ & 1974 & 84 & +7 days & $\begin{array}{l}\text { Untuned } \\
\text { SWD }\end{array}$ & $\begin{array}{l}\text { Non-specific } \\
\text { manipulation }\end{array}$ & $\begin{array}{l}\text { Manipulation group improved immediately, } \\
\text { otherwise results not significant }\end{array}$ \\
\hline Hoehler et al..$^{31}$ & 1981 & 95 & 2-3 weeks & Massage & $\begin{array}{l}\text { Rotational } \\
\text { manipulation }\end{array}$ & Manipulated patients had less pain \\
\hline Mathews et al..$^{32}$ & 1987 & 513 & $\begin{array}{l}1-3 \text { months } \\
2-4 \text { months }\end{array}$ & $\begin{array}{l}\text { 1. Local } \\
\text { anaesthetic } \\
\text { 2. Heat } \\
\text { 3. Heat } \\
\text { 4. Local } \\
\text { anaesthetic }\end{array}$ & $\begin{array}{l}\text { Sclerosant } \\
\text { injection } \\
\text { Manipulation } \\
\text { Traction } \\
\text { Epidural } \\
\text { injection }\end{array}$ & $\begin{array}{l}\text { Non-significant result due to small numbers } \\
30 \% \text { difference in recovery rate after } 6 \text { days } \\
\text { Advantage at } 6 \text { days in treated group over } \\
\text { control group } \\
\text { At } 3 \text { months, treated group had significantly } \\
\text { less pain }\end{array}$ \\
\hline Rasmussen $^{33}$ & 1979 & 24 & 2 weeks & SWD & Manipulation & $92 \%$ improved in 2 weeks \\
\hline $\begin{array}{l}\text { Sims-Williams } \\
\text { et al. }{ }^{36}\end{array}$ & 1978 & 94 & Not stated & $\begin{array}{l}\text { Microwave } \\
\text { diathermy }\end{array}$ & $\begin{array}{l}\text { Mobilization/ } \\
\text { manipulation }\end{array}$ & $\begin{array}{l}\text { Treated group had less pain, felt treatment } \\
\text { helped and could do light work }\end{array}$ \\
\hline
\end{tabular}




\section{Clinical results}

Research seeking to evaluate the effectiveness of manipulative therapy to peripheral joints is scarce, with the majority of trials addressing the problem of low back pain. Research into the effectiveness of manipulative therapy for low back pain has so far failed to demonstrate a long-term benefit significantly better than for other forms of treatment, or indeed of nature alone. There is little evidence that manipulation helps those with severe or chronic back problems ${ }^{24}$, although a non-blind trial comparing chiropractic and hospital outpatient (physiotherapy) treatment, in which both groups used manipulation, concluded that chiropractic confers a long-term benefit in severe and chronic pain when compared to hospital management ${ }^{25}$. However, the validity of these results has been questioned because of flaws in the methodology 26 .

Adequately randomized and controlled clinical trials of spinal mobilization and manipulation have shown a definite, short-term improvement in pain, movement and functional ability, whilst longer term effects are less clear. Direct comparison between the many studies is complicated by the combination of manual therapy with other treatments ${ }^{27}$. Manipulation relieves pain and increases mobility more rapidly in those patients whose symptoms have a short history (Table 2) ${ }^{28-33}$.

A study of cervical manipulation showed that frequency and intensity of migraine, and subsequent disability, was improved with manipulative therapy. Manipulative thrust techniques were not significantly more effective than mobilization alone, and manipulation or mobilization by chiropractors did not produce results that were significantly better than mobilization by physiotherapists ${ }^{37}$.

Evidence exists supporting the use of passive movement of immobilized tissue to prevent and resolve joint contractures, connective tissue atrophy and delayed healing ${ }^{38,39}$.

Several reasons have been identified for the failure to achieve significant results in clinical trials studying low back pain ${ }^{14,40}$. The heterogeneity of the patient group, the subjective nature of pain assessments as a measure of outcome, the interpersonal skills and training of the manipulator, and the impossibility of running a double-blind trial are contributing factors. Single case study methodology may offer a valid alternative for the evaluation of manipulative ther$\operatorname{apy}^{41}$.

\section{Conclusion}

Manipulative therapy encompasses clinical diagnosis and treatment of musculoskeletal pain and dysfunction. A thorough initial analysis of the patient's problem, accurate therapeutic intervention, and evaluation of the subsequent effects is central to the success of this treatment. The therapeutic benefits of manipulative treatment lie mainly with restoration of lost function and the relief of pain. Thus it has much to offer in the management of soft tissue and joint injuries sustained during sport. Clinical trials have shown spinal manipulative therapy to give fast relief of symptoms of short duration, whilst passive movement in general has been shown to have a beneficial effect on immobilized tissue ${ }^{39}$.

\section{References}

1 Lamb DW. A review of manual therapy for spinal pain with reference to the lumbar spine. In: Grieve G, ed. Modern Manual Therapy of the Vertebral Column. Edinburgh: Churchill Livingstone, 1986: 605-21.

2 Blackman J, Prip K. Mobilisation Techniques. 2nd ed. Edinburgh: Churchill Livingstone, 1988.

3 Cyriax J. Textbook of Orthopaedic Medicine, Vol. 2, 11th ed. London: Baillière Tindall, 1984.

4 Hartman L. Classification and application of osteopathic manual techniques. In: Glasgow EF, Twomey LT, Scull ER, Kleynhans AM, eds. Aspects of Manipulative Therapy, 2nd ed. Edinburgh: Churchill Livingstone, 1985.

5 Kaltenborn FM. Mobilisation of the Extremity Joints, 3rd ed. Oslo: Olaf Norlis Bokhandel, 1980.

6 Maitland GD. Vertebral Manipulation, 5th ed. London: Butterworth, 1986.

7 Stoddard A. Manual of Osteopathic Technique, 2nd ed. London: Hutchison, 1962.

8 Wood EC, Becker PD. Beard's Massage, 3rd ed. Philadelphia: WB Saunders Company, 1981.

9 Wale JO. Tidy's Massage and Remedial Exercises, 11th ed. Bristol: J Wright and Sons, 1968.

10 Wakim KG. In: Rogoff JB, ed. Manipulation Traction and Massage, 2nd ed. Baltimore: Williams and Wilkins, 1980.

11 Bogduk N, Twomey LT. Clinical Anatomy of the Spine. Edinburgh: Churchill Livingstone, 1987.

12 MacConnaill MA, Basmajian JV. Muscles and Movement. New York: Krieger Publishing, 1977.

13 Blackman J. Manipulation: a personal view. In: Grieve G, ed. Modern Manual Therapy of the Vertebral Column. Edinburgh: Churchill Livingstone, 1986: 656-60.

14 Wells PE. Manipulative procedures. In: Wells PE, Frampton $\mathrm{V}$, Bowsher D, eds. Pain Management and Control in Physiotherapy. London: Heinemann, 1988.

15 Grieve GP. Common Vertebral Joint Problems. Edinburgh: Churchill Livingstone, 1981.

16 Wyke BD. The neurology of joints. Ann R Coll Surg Engl 1987; 41: 25-50.

17 Wyke BD. Articular neurology and manipulative therapy. In: Glasgow EF, Twomey LT, Scull ER, Kleynhans AM, eds. Aspects of Manipulative Therapy, 2nd ed. Edinburgh: Churchill Livingstone, 1985.

18 Melzack R, Wall PD. Pain mechanisms: a new theory. Science 1965; 150: 971-9.

19 Zusman M. Reappraisal of a proposed neurophysiological mechanism for the relief of pain with passive movements. Physiother Pract 1985; 1: 64-70.

20 Watson J. Pain mechanisms: a review 3. Endogenous pain mechanisms. Aust J Physiother 1982; 28: 38-45.

21 Zusman M. Spinal manipulative therapy; review of some proposed mechanisms, and a new hypothesis. Aust J Physiother. 1986; 32: 89-97.

22 Binkley J. Overview of ligament and tendon structure and mechanics: implications for clinical practice. Physiother Canada 1989; 41: 24-9.

23 Woo SL-Y, Gomez MA, Amiel D, Ritter MA, Gelberman RH, Akeson WH. The effects of exercise on the biomechanical and biochemical properties of swine digital flexor tendon. $J$ Biomech Eng 1981; 103: 51-6.

24 Sims-Williams HL, Jayson MIV, Young SMS, Baddeley $\mathrm{H}$, Collins E. Controlled trial of mobilisation and manipulation for patients with low back pain: hospital patients. $\mathrm{Br}$ Med J 1979; ii: $1318-20$.

25 Meade TW, Dyer S, Browne W, Townsend J, Frank O. Low back pain of mechanical origin: randomised comparison of chiropractic and hospital out patient treatment. $\mathrm{Br}$ Med J 1990; 300: 1431-7.

26 Partridge C. Letter. Physiotherapy 1990; 76: 457.

27 Di Fabio RP. Clinical assessment of manipulation and mobilisation of the lumbar spine. Phys Ther 1986; 66: 51-4.

28 Evans DP, Burke MS, Lloyd KN, Roberts EE, Roberts GM Lumbar spinal manipulation on trial. Part 1. Rheumatol Rehabil 1978; 17: 46-53. 
29 Fisk JW. A controlled trial of manipulation in a selected group of patients with low back pain favouring one side. $\mathrm{N} \mathrm{Z} \mathrm{Med} \mathrm{J}$ 1979; 89: 346-8.

30 Glover JR, Morris J, Khosla T. Back pain: a randomised clinical trial of rotational manipulation of the trunk. $\mathrm{Br} J$ Ind Med 1974; 31: 59.

31 Hoehler FK, Tobis JS, Buerger AA. Spinal manipulation for low back pain. JAMA 1981; 245: 1835-8.

32 Mathews JA, Mills SB, Jenkins VM et al. Back pain and sciatica: controlled trials of manipulation, traction, sclerosants and epidural injections. Br J Rheumatol 1987; 26: 416-23.

33 Rasmussen GG. Manipulation in treatment of low back pain (randomised clinical trial). Manuelle Medezin 1979; 17: 8-10.

34 Berquist-Ullman M, Larson U. Acute low back pain in industry. Acta Ortho Scand 1977; 170(Suppl): 1-117.

35 Coxhead CE, Inskip H, Mead TW, North WRS, Troup JDG. Multicentre trial of physiotherapy in the management of sciatic symptoms. Lancet 1981; i: 1065-8.
36 Sims-Williams HL, Jayson MIV, Young SMS, Baddeley $\mathrm{H}$, Collins E. Controlled trial of mobilization and manipulation for patients with low back pain in general practice. $\mathrm{Br}$ Med J 1978; ii: $1338-40$.

37 Parker GB, Tupling H, Pryor DS. A controlled trial of cervical manipulation for migraine. Aust NZ J Med 1978; 8: 589-93.

38 Akeson WH, Amiel D, Abel MF, Garfin SR, Woo S-Y. Effects of immobilisation on joints. Clin Orthop 1987; 219: 28-37.

39 Frank C, Akeson WH, Woo SL-Y, Amiel D, Coutts RD. Physiology and therapeutic value of passive motion; Clin Orthop 1984; 185: 113-25.

40 O'Donoghue CE. Manipulation trials. In: Grieve GP, ed. Modern Manual Therapy of the Vertebral Column. Edinburgh: Churchill Livingstone, 1986: 849-59.

41 Ottenbacher KJ. Evaluating Clinical Change. Baltimore: Williams and Wilkins, 1986. 